\title{
PEMBUATAN PAKAN KOMPLIT BLOK BERBASIS LIMBAH PERTANIAN DAN INDUSTRI PANGAN UNTUK PENGGEMUKAN SAPI DI DISTRIK PRAFI KABUPATEN MANOKWARI
}

\author{
B. Santoso ${ }^{1}$, B. Tj. Hariadi ${ }^{2}$, T. W. Widayati ${ }^{3}$
}

\begin{abstract}
ABSTRAK
Tujuan dari kegiatan Program Kemitraan Masyarakat (PKM) adalah untuk memperkenalkan teknologi pembuatan pakan komplit blok berbasis limbah pertanian, pekebuanan dan industri pangan. Kegiatan ini dilaksanakan selama 8 bulan (Maret-Oktober 2018) di Kampung Aimasi dan Kampung Udapi Hilir, Distrik Prafi, Kabupaten Manokwari. Dua kelompok petrnak yang menjadi mitra kegiatan adalah Kelompok Harapan Makmur dan Kelompok Tani Ternak Terpadu 11. Hasil kegiatan menunjukkan bahwa peserta kegiatan mempunyai respon yang baik terhadap materi yang diberikan. Ternak sapi dan kambing mempunyai preferensi yang baik terhadap pakan komplit blok yang diberikan.
\end{abstract}

Kata kunci : pakan komplit blok, jerami padi, limbah, pelepah kelapa sawit, peternak

\begin{abstract}
The aim of Program Kemitraan Masyarakat activity was to introduce the technology of making complete feed block based on agricultural, and food industry by-products. The activity was conducted during 8 months (March to October 2018) at Aimasi and Udapi Hilir Villages, Prafi District, Manokwari Regency. The two groups of farmers who became the activity partners were Kelompok Harapan Makmur and Kelompok Tani Ternak Terpadu 11. The results of the activity indicate that the activity participants have a good response to the material provided. Cattle and goats have a good preference to the complete feed block.
\end{abstract}

Keywords : complete feed block, rice straw, by-product, palm oil frond, farmer

\section{PENDAHULUAN}

Pada umumnya petani peternak di Kampung Aimasi dan Kampung Udapi Hilir, Distrik Prafi memelihara ternak sapi menggunakan sistem semi-intensif yaitu ternak dibiarkan merumput di sekitar lahan pertanian pada siang hari dan dimasukkan dalam kandang pada malam hari. Pada waktu-waktu tertentu misalnya pada saat turun hujan peternak memberikan pakan kepada sapi berupa hijauan seperti rumput gajah dan rumput raja baik ada di sekitar rumah maupun yang diambil dari areal pertanian. Sering dijumpai pula, peternak memberikan pakan hanya untuk memenuhi kebutuhan pokok tanpa memperhitungkan kebutuhan untuk berproduksi. Hal ini menyebabkan pertambahan bobot badan yang dihasilkan oleh ternak-ternak tersebut tidak maksimal.

Sapi potong membutuhkan sejumlah zat-zat makanan seperti protein, energi dan mineral untuk memenuhi kebutuhan berbagai fungsi tubuh yaitu kebutuhan hidup pokok dan kebutuhan produksi. Kebutuhan hidup pokok adalah kebutuhan untuk memenuhi proses hidup pokok saja tanpa pertumbuhan dan produksi, sedangkan kebutuhan untuk produksi merupakan kebutuhan untuk pertumbuhan, produksi susu dan untuk pertumbuhan janin apabila ternak perah sedang bunting.

\footnotetext{
${ }^{I}$ Jurusan Peternakan, Fakultas Peternakan Universitas Papua, Manokwari, Papua Barat, b.santoso@unipa.ac.id

${ }^{2}$ Jurusan Peternakan, Fakultas Peternakan Universitas Papua, Manokwari, Papua Barat

${ }^{3}$ Jurusan Peternakan, Fakultas Peternakan Universitas Papua, Manokwari, Papua Barat
} 
Populasi sapi potong di Kabupaten Manokwari pada tahun 2016 sebanyak 24.556 ekor yang sebagian besar $(22,9 \%)$ dipelihara oleh penduduk daerah transmigrasi terutama di Distrik Prafi (BPS Provinsi Papua Barat, 2017). Kabupaten Manokwari sangat potensial untuk pengembangan usaha peternakan karena didukung dengan sumberdaya alam yang sangat memadai untuk ternak. Kabupaten Manokwari juga merupakan daerah yang cukup untuk penyediaan pakan ternak, baik pakan hijauan maupun limbah pertanian seperti jerami padi dan perkebunan seperti pelepah kelapa sawit

Limbah pertanian dan perkebunan yang potensial di Kabupaten Manokwari berturut-turut jerami padi dan pelepah kelapa sawit. Luas lahan panen padi di Kabupaten Manokwari $3.828 \mathrm{Ha}(53,4 \%)$ (BPS Provinsi Papua Barat, 2016). Rata-rata produksi jerami padi per hektar per panen dapat mencapai 5-8 ton (Setioko dan Haryanto, 2002), sehingga estimasi produksi jerami padi di Kabupaten Manokwari dapat mencapai 19.140 ton per panen.

Berdasarkan laporan BPS Provinsi Papua Barat (2016) bahwa luasan areal kelapa sawit di Kabupaten Manokwari adalah 21.370 Ha. Pelepah kelapa sawit merupakan salah satu limbah dari perkebunan kelapa sawit. Siklus pemangkasan pelepah setiap 14 hari dan tiap pemangkasan dihasilkan 3 pelepah daun dengan berat $10 \mathrm{~kg} /$ pelepah. Berdasarkan data tersebut terlihat bahwa jerami padi dan pelepah kelapa sawit di Kabupaten Manokwari mempunyai potensi yang besar untuk digunakan sebagai sumber energi dan pakan serat untuk sapi potong.

Pada umumnya limbah pertanian dan perkebunan mengandung serat kasar yang tinggi dan palatabilitasnya rendah, sehingga menjadi faktor pembatas penggunaannya sebagai pakan ternak ruminansia (Santoso and Hariadi, 2009). Oleh sebab itu, salah satu alternatif pemanfaatan limbah tersebut yaitu dengan menggabungkan beberapa limbah pertanian, perkebunan dan industri pangan menjadi suatu pakan komplit blok (complete feed blok).

Keuntungan pemberian pakan komplit pada ternak ruminansia adalah dapat mempertahankan stabilitas rumen, memperkecil hasil fermentasi yang hilang dan menjamin penggunaan amonia yang optimal (Prasad et al., 2001). Pembuatan pakan komplit blok dari bahan pakan yang bersifat bulky dapat menurunkan kebutuhan ruang penyimpanan dan biaya transportasi (Samanta et al., 2003).

Dengan melihat potensi jerami padi dan pelepah kelapa sawit yang melimpah di Distrik Prafi serta belum dimanfaatkan sebagai pakan ternak sapi, maka perlu dilakukan sosialisasi dan demonstrasi tentang pembuatan pakan komplit berbasis jerami padi dan pelepah kelapa sawit dalam upaya meningkatkan performans sapi potong yang ada di daerah tersebut.

\section{METODE PELAKSANAAN}

Program Kemitraan Masyarakat berlangsung selama 8 bulan yaitu Mei sampai dengan Oktober 2018 di Kampung Aimasi SP (Satuan Pemukiman) 3 dan Kampung Udapi Hilir SP 4, Distrik Prafi Kabupaten Manokwari. Peternak yang menjadi mitra pada kegiatan ini adalah Kelompok Harapan Makmur dan Kelompok Tani Ternak Terpadu Sebelas (Klotter 11) dengan anggota berturutturut sebanyak 25 orang dan 11 orang. Kegiatan yang dilaksanakan meliputi persiapan bahan pakan, pengurusan ijin sosialisasi dan demonstrasi pembuatan pakan komplit blok, dan uji coba pakan pada sapi dan kambing.

\subsection{Persiapan Bahan Pakan}

Jerami padi dan pelepah kelapa sawit berturut-turut diambil dari areal persawahan dan kebun kelapa sawit yang ada di SP3 dan SP4 Distrik Prafi. Jerami padi dikeringkan di bawah sinar matahari, kemudian dicacah menggunakan mesin chopper. Pelepah kelapa sawit dicacah menggunakan mesin chopper kemudian dikeringkan di bawah sinar matahari. Onggok dan ampas tahu diambil dari beberapa industri pembuatan tepung tapioka dan tahu skala rumah tangga yang ada di sekitar lokasi kegiatan kemudian dikeringkan dan digiling halus.

\subsection{Persiapan dan Pelaksanaan Sosialiasi dan Demonstrasi}


Kegiatan yang dilakukan dalam tahap persiapan sosialisasi meliputi koordinasi dengan dengan Lembaga Ppenelitian dan Pengabdian kepada Masyarakat Universitas Papua untuk penerbitan surat pengantar kepada kepala distrik. Selanjutnya kepala distrik akan melakukan koordinasi dengan kepala kampong berkaitan tempat dan waktu pelaksanaan sosialissi dan demonstrasi pembuatan pakan komplit blok.

\subsection{Pelaksanaan Sosialisasi dan Demonstrasi Pembuatan Pakan Komplit Blok}

Kegiatan sosialisasi dan demonstrasi dilaksanakan di Balai Kampung Aimasi, SP 3 Distrik Prafi. Peserta kegiatan adalah anggota kelompok Harapan Makmur dan Kelompok Tani Ternak Terpadu 11, aparat kampung, penyuluh pertanian/peternakan. Tujuan kegiatan ini adalah unutk memberikan pengetahuan kepada peternak tentang cara pembuatan pakan komplit blok berbasis limbah pertanian, perkebunan dan industri pangan. Sosialisasi dilakukan dengan metode ceramah menggunakan infocus dan setiap peserta diberikan handout dan leaflet. Setelah ceramah dilanjutkan tanya jawab antara peserta dengan pemateri (Gambar 1).
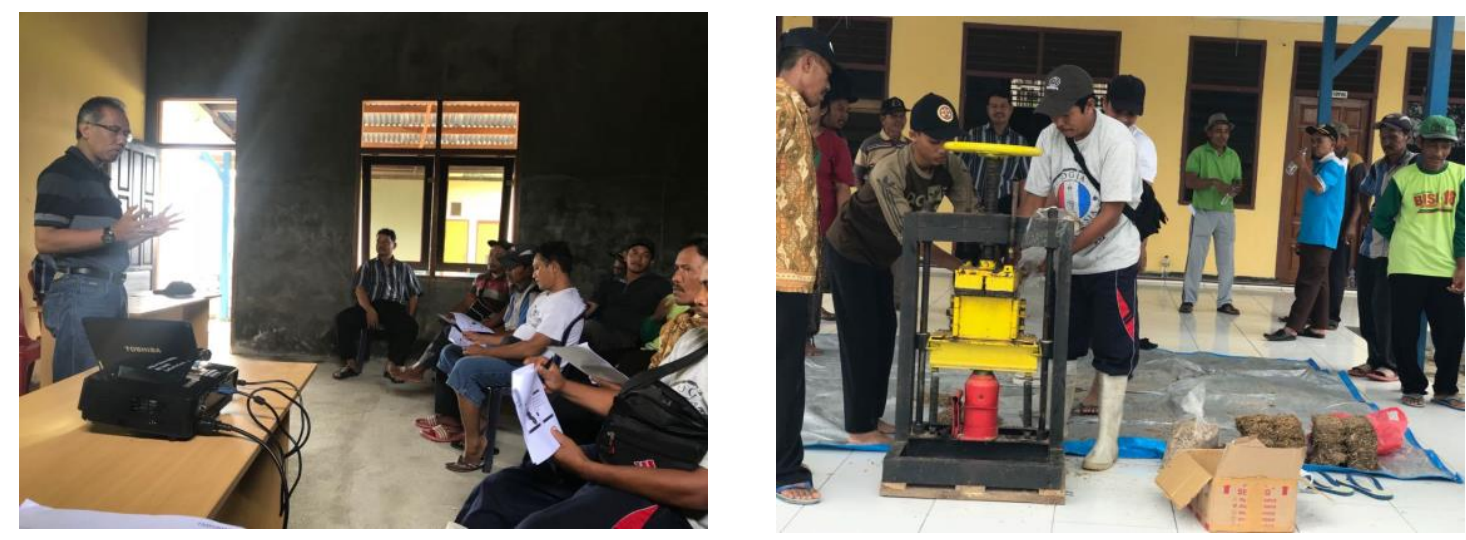

Gambar 1. Penyampaian Materi dan Demonstrasi Pembuatan Pakan Komplit Blok

Pada demonstrasi ini, total bahan pakan yang digunakan untuk membuat pakan komplit blok sebanyak $100 \mathrm{~kg}$. Jenis dan persentase bahan pakan yang digunakan untuk pembuatan pakan komplit blok disajikan pada Tabel 1.

Tabel 1. Jenis dan Jumlah Bahan Pakan Penyusun Pakan Komplit Blok

\begin{tabular}{|c|l|c|}
\hline No. & \multicolumn{1}{|c|}{ Bahan pakan } & Jumlah $(\mathbf{k g})$ \\
\hline 1. & Jerami padi & 12 \\
\hline 2. & Pelepah sawit & 25 \\
\hline 3. & Onggok & 23 \\
\hline 4. & Ampas tahu & 17 \\
\hline 5. & Molases & 20 \\
\hline 6. & Urea $\quad$ Jumlah & 1,5 \\
\hline 7. & Campuran mineral & 1,5 \\
\hline & \multicolumn{2}{|c|}{} \\
\hline
\end{tabular}

Setelah semua bahan pakan dicampur, maka campuran bahan pakan dicetak dalam alat pres hidrolik dengan volume setiap pakan blok sebanyak $300 \mathrm{~g}$.

\subsection{Uji Preferensi Sapi dan Kambing Terhadap Pakan Komplit Blok}


Pakan komplit blok berbasis limbah pertanian, perkebunan dan industri pangan diuji pada ternak sapi dan kambing selama 30 hari (Gambar 2). Uji pakan pada ternak sapi dilakukan di Kampung Aimasi SP 3 Distrik Prafi, sedangkan uji pada ternak kambing dilakukan di Laboratorium Lapang, Fakultas Peternakan Universitas Papua.
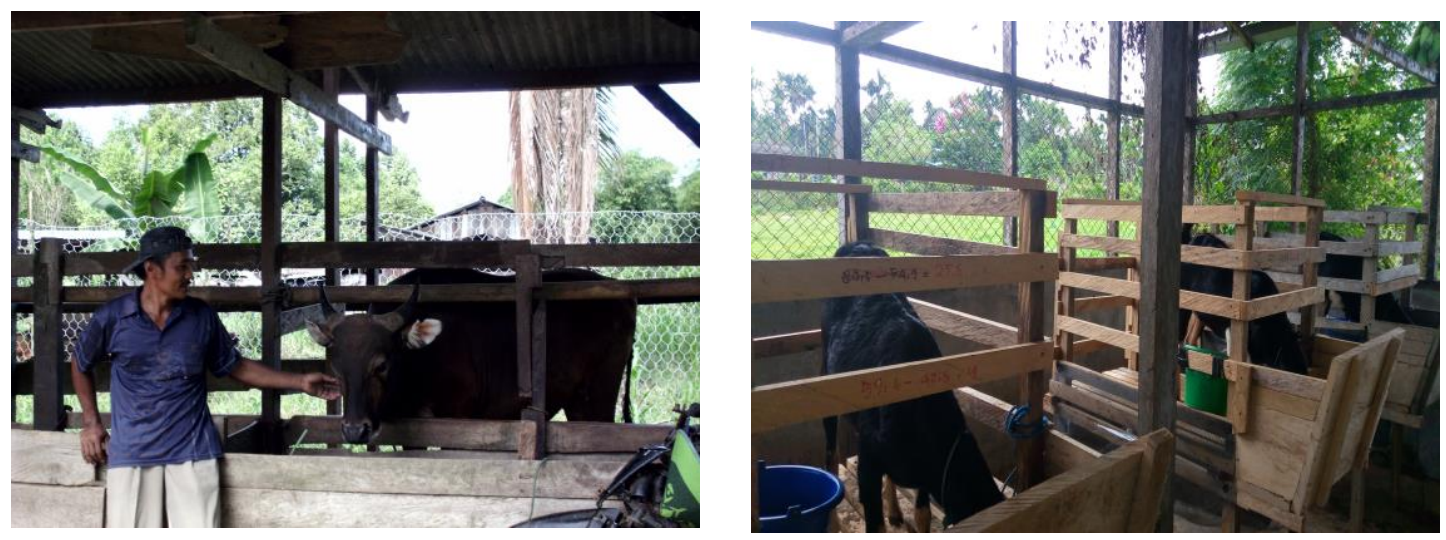

Gambar 2. Uji Preferensi Pakan pada Ternak Sapi dan Kambing

\section{HASIL DAN PEMBAHASAN}

\subsection{Kegiatan Sosialisasi}

Kegiatan sosialisasi dan demonstrasi tentang pembuatan pakan komplit blok berbasis limbah pertanian, perkebunan dan industri pangan untuk ternak ruminansia berlangsung selama \pm 3 jam yang diikuti oleh 23 peserta. Pada bagian akhir sosialisasi, peserta diberikan kesempatan untuk bertanya dan diskusi dengan narasumber. Peserta sosialisasi sangat tertarik dengan materi yang disampaikan, hal ini diindikasikan dari banyaknya peserta yang mengajukan pertanyaan. Pada umumnya petani peternak di SP3 dan SP4 Distrik Prafi tidak menggunakan jerami padi sebagai pakan ternak. Jerami padi tersebut dibiarkan sampai kering di areal persawahan dan selanjutnya jerami yang telah kering dibakar sebelum petani memulai penanaman kembali. Padahal jerami padi masih mengandung zatzat makanan yang dapat digunakan oleh ternak ruminansia. Santoso et al. (2009) melaporkan bahwa jerami padi mengandung bahan organik dan nitrogen berturut-turut $81,1 \%$ dan $1,1 \%$. Santoso et al. (2016) melaporkan bahwa pelepah kelapa sawit yang diperoleh dari perkebunan di Distrik Prafi mempunyai komposisi kimia sebagai berikut bahan kering 22,5\%, bahan organik $82,7 \%$, protein kasar 4,4\%, NDF 79,2\%, ADF 63,4\% dan energi bruto 3,96 kkal/g. Para peserta sangat tertarik dengan materi yang disampaikan, karena seluruh peserta kegiatan selain sebagai peternak juga melakukan aktivitas bercocok tanam padi dan buruh di lokasi perkebunan kelapa sawit. Mereka menyadari bahwa jerami padi yang merupakan limbah dari kegiatan pertanian selama ini belum dimanfaatkan secara maksimal, dan sebagian besar limbah tersebut hanya dibiarkan menjadi kering dan selanjutnya dibakar.

\subsection{Kualitas Pakan Pakan Komplit Blok}

Kandungan nutrien pakan komplit blok berbasis limbah pertanian, perkebunan dan industri pangan tertera pada Tabel 2.

Tabel 2. Komposisi Kimia (\%) Pakan Komplit Blok 


\begin{tabular}{|l|c|}
\hline \multicolumn{1}{|c|}{ Nutrien } & Komposisi (\%) \\
\hline Bahan Kering & 78,3 \\
\hline Bahan Organik & 90,5 \\
\hline Protein Kasar & 14,7 \\
\hline NDF & 55,2 \\
\hline ADF & 36,9 \\
\hline Hemiselulosa & 18,3 \\
\hline
\end{tabular}

Kandungan bahan kering pakan komplit blok hampir sama dengan nilai yang diperoleh pada penelitian Santoso et al. (2017) yaitu 78,7\%. Pakan yang mengandung nilai protein kasar sebesar $14,7 \%$ dapat digunakan untuk memenuhi kebutuhan sapi potong yang mempunyai bobot badan 300 $\mathrm{kg}$ dengan pertambahan bobot badan $750 \mathrm{~g} /$ hari (Kearl, 1982).

\subsection{Uji Preferensi Pakan Komplit Blok}

Uji preferensi pakan komplit blok pada ternak sapi dilaksanakan di SP 3 Distrik Prafi, sedangkan uji pada ternak kambing di Laboratorium Lapang Fakultas Peternakan. Pada uji preferensi tersebut ternak sapi dan kambing membutuhkan waktu adaptasi selama 10-14 hari untuk mengkonsumsi $100 \%$ pakan komplit blok. Ternak kambing mampu mengkonsumsi pakan komplit blok sebanyak $2,8 \%$ bahan kering dari bobot badannya. Walaupun komposisi pakan komplit tersebut tersusun dari $25 \%$ jerami padi dan $17 \%$ pelepah kelapa sawit yang mengandung serat kasar yang tinggi, namun setelah dicampur dengan bahan pakan lain maka pakan komplit blok tersebut menjadi palatable. Sebagaimana dikemukakan oleh Prasad et al. (2001) bahwa pemberian pakan komplit dapat meningkatkan penggunaan hijauan berkualitas rendah dan memperbaiki palatabilitas pakan non konvensional.

\section{KESIMPULAN DAN SARAN}

\subsection{Kesimpulan}

1. Anggota Kelompok Peternak Harapan Makmur dan Kelompok Tani Ternak Terpadu Sebelas yang menjadi sasaran kegiatan memberikan respon yang baik terhadap introduksi teknologi pembuatan pakan komplit blok berbasis limbah pertanian, perkebunan dan industri pangan.

2. Pakan komplit blok berbasis limbah pertanian, perkebuanan dan industri pangan memliki palatabilitas yang baik sehingga tidak mempengaruhi konsumsi pakan ternak sapi dan kambing.

\subsection{Saran}

Perlu adanya bantuan alat pencacah pelepah kelapa sawit dan alat pres pakan blok kepada kelompok peternak dari pemerintah daerah melalui instasi terkait sehingga peternak dapat mengaplikasikan teknologi pakan.

\section{UCAPAN TERIMA KASIH}

Penulis mengucapkan terima kasih kepada Direktorat Riset dan Pengabdian Masyarakat, Kementerian Riset Teknologi dan Pendidikan Tinggi yang telah menyediakan dana melalui Program Kemitraan Masyarakat dengan Surat Kontrak Pengabdian No. 036/SP2H/LT/DRPM/2018. Penulis juga mengucapkan terima kasih kepada Bapak Soeparno, S.Pt. yang telah membantu dalam persiapan dan pelaksanaan kegiatan ini.

\section{DAFTAR PUSTAKA}

BPS Provinsi Papua Barat. (2017), Papua Barat Dalam Angka. Badan Pusat statistik Provinsi Papua Barat. 
Kearl, L.C. (1982), Nutrient Requirements of Ruminants in Developing Countries. Utah State University, Utah.

Prasad, C.S., N.K.S. Gowda and J.V. Rammana (2001), Feeding strategies to enhance animal productivity. In: Proceedings of the Xth Animal Nutrition Conference, NDRI, Karnal, India, Pp. 23-45.

Santoso, B. and B. Tj. Hariadi. (2009), Evaluation of nutritive value and in vitro methane production of feedstuffs from agricultural and food industry by-products. J. Indon. Trop. Anim. Agric. Vol 34, pp 190196.

Santoso B., M.N. Lekitoo dan B.Tj. Hariadi. (2016), Pengembangan Teknologi Pembuatan Pakan Komplit Blok Berbasis Limbah Pertanian yang Diperkaya Probiotik untuk Meningkatkan Produktivitas Ternak Ruminansia. Laporan Penelitian. Fakultas Peternakan, Universitas Papua.

Samanta, A.K., K.K. Singh, M.M. Das, S.B. Maity and S.S. Kundu (2003), Effect of complete feed block on nutrient utilisation and rumen fermentation in barbari goats. Small Rum. Res. Vol 48, pp. 95-102.

Setioko, A.R. dan B. Haryanto (2002), Teknologi Fermentasi Jerami Sebagai Nilai Tambah dan Solusi dalam Penyediaan Pakan Alternatif Ternak Sapi Potong. Laporan Penelitian. Balai Penelitian Ternak Ciawi, Bogor. 